\title{
Philosophy, Welfare and Aging
}

\author{
Jason L. Powell \\ University of Chester, UK. \\ j.powell@chester.ac.uk
}

*Corresponding Author: Prof. Jason Powell, PhD, FHEA, FRSPH, FRSA, Department of Social and Political Science, Westminster Building, The University of Chester, Parkgate Road, Chester, CH1 4BJ, UK.

\section{Abstract}

This article examines the way in which philosophical theory can enhance our understanding of aging identity with specific reference to the range of philosophical which have emerged over the past 30 years. In particular, the paper is concerned with locating and scrutinising the accelerating theoretical developments in philosophical gerontology and moves to reviewing their fundamental concerns. The different philosophies which have materialised exemplify an interpretation of the consequences Welfarepolicy has for older people. This opens up the pathway to understanding philosophical gerontology more creatively.

Keywords: Philosophy, Aging, Philosophy of age, Disengagement and Inequalities

\section{INTRODUCTION}

There has been a huge rise and consolidation of philosophical publications relating to age and aging that has cut right across and through philosophical and human sciences (Bury 1995; Powell, 2018). Philosophical Gerontology is multidisciplinary and is the principal instrument of orthodox theorising about old age particularly in US, UK and Australasian academies (Phillipson 1998; Biggs and Powell 2001; Powell, 2018). Turner (1989) and Phillipson (1998) both acknowledge that philosophical theory must be brought into the frame of analysing old age.

This articleaddresses this challenge and is concerned with highlighting the major theoretical ideas which have informed philosophical understanding of age and aging in recent years. The analysis of the major theoretical ideas which have influenced understanding of philosophical gerontology in recent years: functionalism, marxism, feminism and postmodernism. It is important to illuminate the contrasting philosophical of age and aging, as research papers in mainstream philosophical gerontology have not attempted to review these philosophies in an attempt to understand the philosophical dimensions of human experience.
Philosophical Theory and The Rise of Functionalist Accounts of Age AND AGING

The emergence and consolidation of philosophies of age can be located to the early post-war years with the concern about the consequences of demographic change and the potential shortage of 'younger' workers in US and UK and impact on Welfare care and pensions. Philosophical gerontology emerged as a field of study which attempted to respond to the philosophical policy implications of demographic change (Vincent 1996). Such disciplines were shaped by significant external forces. First, by state intervention to achieve specific outcomes in Welfare policy; secondly, by a political and economic environment which viewed an aging population as creating a 'philosophical problem' for society (Jones, 1993). This impinged mainly upon the creation of functionalist accounts of age and aging primarily in US academies. Functionalist sociology dominated the sociological landscape in the USA from the 1930's up until 1960s (Powell, 2018; Blaikie 1999). Talcott Parsons was a key exponent of general functionalist thought and argued that society needed certain functions in order to maintain its well-being: the stability of the family; circulation of elites in 
education drawing from a "pool of talent" (Giddens 1993). Society was seen as akin to a biological organism - all the parts (education/family/religion/ government) in the system working together in order for society to function with equilibrium (Giddens 1993; Powell, 2018).

The important point to note is that philosophical often mirror the norms and values of their creators and their philosophical times, reflecting culturally dominant views of what should be the appropriate way to analyse philosophical phenomena. The two philosophical which dominated American gerontology in the 1950s of Disengagement and Activity theory follow this normative pattern. Both disengagement and activity philosophical postulate not only how individual behaviour changes with aging, but also imply how it should change (Powell, 2018).

This was seen in the United States via the dominance of the structural-functionalist school via the work of 'disengagement theorists' (Phillipson 1998). Such major protagonists of disengagement theory was Cumming and Henry (1961) who looked at how older people should disengage from work roles and prepare for the ultimate disengagement: death (Powell 2018). There are two broad schools of thought within the functionalist umbrella theory: Disengagement theory and Activity theory. The former is the most controversial. Disengagement theory is associated with Cumming and Henry (1961) and proposes that gradual withdrawal of older people from work roles and philosophical relationships is both an inevitable and natural process:

...withdrawal may be accompanied from the outset by an increased preoccupation with himself: certain institutions may make it easy for him' (Cumming and Henry 1961: 14).

For this variant of functionalism, this process benefits society, since it means that the death of individual society members does not prevent the ongoing functioning of the philosophical system. Cumming and Henry (1961) further propose that the process of disengagement is inevitable, rewarding and universal process of mutual withdrawal of the individual and society from each other with advancing age - was normal and to be expected. This theory argued that it was beneficial for both the aging individual and society that such disengagement takes place in order to minimise the philosophical disruption caused at an ageing person's eventual death (Neurgarten 1998).

Retirement is a good illustration of disengagement process, enabling the aging person to be freed of the responsibilities of an occupation and to pursue other roles not necessarily aligned to full-pay of economic generation. Through disengagement, Cumming and Henry argued, society anticipated the loss of aging people through death and brought "new blood" into full participation within the philosophical world (cited in Katz 1996). Bronley (1966: 136) further portends 'in old age, the individual is normally disengaged from the main streams of economic and community activity'. Not surprisingly for Bromley (1966 quoted in Bond and Coleman 1993: 44)) 'The (disengagement) process is graded to suit the declining biological and psychological capacities of the individual and the needs of society'.

A number of critiques exist: firstly, this theory condones indifference towards 'old age' and philosophical problems (Bond \& Coleman 1993). Secondly, disengagement theory underplays the cultural and economic structures have in creating, with intentional consequences of, withdrawal. This theory engages in sociological reductionism in pre-supposing that 'old age' is bound up with the explanation of 'disengagement' and engages in 'functional teleology' (Giddens 1993) in attempting to explain old age in terms of its effects or 'death'. Also, Kastenbaum (1993) claims disengagement theory represented a threat to the promotion of a positive and involved lifestyle for ageing persons across the lifecourse. Both advocate a retired old age as a 'natural' period of transition. In order to legitimise its generalisations, disengagement theory self-praised itself to objective and value-free rigour of research methods: survey and questionnaire methods of gerontological inquiry. In a sense, by arguing for 'disengagement' from work roles under the guise of objectivity is a very powerful argument for governments to legitimise boundaries of who can work and who cannot based on age (Powell 1999; Powell, 2018).

Activity theory is a counterpoint to disengagement theory, since it claims a successful 'old age' is can be achieved by maintaining roles and relationships. Activity theory actually pre-dates disengagement Open Journal of Geriatrics V1 . I2 . 2018 
theory. In the 1950s Havighurst and Albrecht (1953 cited in Katz 1996) insisted ageing can be lively and creative experience. Any loss of roles, activities or relationships within old age, should be replaced by new roles or activities to ensure happiness, value consensus and well-being. For activity theorists, disengagement is not a natural process as advocated by Cumming and Henry. For activity theorists, disengagement theory is inherently ageist and does not promote in any shape or form 'positive ageing'. Thus, "activity" was seen as an ethical and academic response to the disengagement thesis which re-casted retirement as joyous and mobile (Powell, 2018).

Nevertheless, Activity theory neglects issues of power, inequality and conflict between age groups. An apparent 'value consensus' may reflect the interests of powerful and dominant groups within society who find it advantageous to have age power relations organised in such a way. Whilst Phillipson (1998) sees such functionalist schools as important in shaping philosophical theory responses to them, such functionalist philosophical 'impose' a sense of causality on aging by implying you will either 'disengage' or will be 'active'. This can be argued to be a form of 'academic imperialism' where the activities of aging people are dictated to and from theoretical models which reconstruct age and aging along lines of enforced experiences. They are very macro orientated and fail to resolve tensions within age-group relations which impinge upon the inter-connection of 'race', class and gender with age.

\section{Political Economy}

As an intellectual backdrop against such functionalist theoretical dominance, Political Economy of Old Age emerged as a fashionable theory in both sides of the Atlantic, drawing from Marxian insights in analysing the capitalist complexity of modern society and how old age was philosophically constructed to foster the needs of the economy (Estes 1979). This critical branch of Marxist gerontology grew as a direct response to the hegemonic dominance of structural functionalism in the form of disengagement theory, the biomedical paradigm and world economic crises of the 1970s. As Phillipson (1998) points out in the UK huge forms of philosophical expenditure were allocated to older people. Consequently, not only were older people viewed in medical terms but in resource terms by governments. This brought a new perception to attitudes to age and aging. As Phillipson (1998: 17) teases out:

'Older people came to be viewed as a burden on western economies, with demographic change... seen as creating intolerable pressures on public expenditure'.

A major concern of 'political economy of old age' was to challenge both the theoretical dominance of functionalist thought and biomedical models of age and aging. The political economy approach wanted to have an understanding of the character and significance of variations in the treatment of the aged, and to relates these to polity, economy and society in advanced capitalist society.

The major focus is an interpretation of the relationship between aging and the economic structure. In the USA, Political Economy theory was pioneered via the work of Estes (1979), and Estes, Swan and Gerard (1982). Similarly, in the UK, the work of Walker (1981), Townsend (1981) and Phillipson (1982) added a critical sociological dimension to understanding age and ageing in advanced capitalist societies. For Estes, Swan and Gerard (1982) in the U.S.A, the class structure is perceived as the major determinant of the socio-economic position of older people in advanced capitalist society. For Estes (1979) political economy challenges the ideology of older people as belonging to a homogenous group unaffected by dominant structures in society. Estes (1979) claims political economy focuses upon an analysis of the state in contemporary societal formations. Here, we can see how Marxism is inter-connected to this theory. Estes looks to how the state decides and dictates who is allocated resources and who is not. This impinges upon retirement and subsequent pension schemes. As Phillipson (1982) points out, the retirement experience is linked to the timing of economic reduction of wages and enforced withdrawal from work has made many older people in the UK in a financially insecure position. Hence, the state can make and break the fortunes of its populace. Consequently, current governmental discourses of cutting public expenditure on pensions and increasingly calling for private provision legitimises ideological mystification stereotypes of "burden" 
groups and populations. In the USA, Estes, Swann and Gerard (1982) claims that the state is using its power to transfer responsibility of welfare provision from the state and onto individuals. Indeed, blaming people for non-provision of own savings obscures and mystifies that real economic problems derive from the capitalist mode of production and political decisions (Powell 2018).

American Political Economy then is a 'grand' theory drawing from Marxian historiography, locates the determining explanatory factors in the structure of society and focuses upon welfare and its contribution to the institutional decommodification of retired older people. Negative attitudes towards older people and impoverished position are best explained by the latter's loss of philosophical worth brought about by their loss of a productive role in American society that puts premium on production (Estes et al. 1982).

Similarly, this is an argument reiterated by critical gerontological writers in the U.K on the philosophical position of older people. In particular, Townsend (1981) observes that society creates the philosophical problems of old age through 'structured dependency' embedded in institutional agism through lack of material resources via poverty, retirement policies, negative consequences of residential care, and passive forms of community care services (Powell, 2018). Townsend focuses on a 'structural' perspective of 'rules and resources' governing older people in advanced capitalism and wider philosophical system. Importantly, Townsend claims is approach as:

'one whereby society is held to create the framework of institutions and rules within which the general problem of the elderly emerge or, indeed, "manufactured". In the everyday management of the economy and the administration and development of philosophical institutions the position of the elderly subtly changed and shaped'. (Townsend 1981: 9)

Similarly, Walker (1981) argued for a 'political economy of old age' in order to understand the position of older people. In particular, Walker (1981: 77) paid attention to the 'philosophical creation of dependency' and how philosophical structure and relations espoused by the mode of production which helps intensify structural class marginalisation. In a similar vein, Phillipson $(1982,1986)$ considers how capitalism helps philosophically construct the philosophical marginality of older people in key areas such as welfare delivery. The important argument to be made is that inequalities in the distribution of resources should be understood in relation to the distribution of power within society, rather than in terms of individual variation.

\section{FEMinist GERONTOLOGY}

Coupled with the above, there has been an acceleration of Feminist insights into understanding age and gender as key identity variables of analysis (Arber \& Ginn 1991 and 1995). There are two important issues: first, power imbalances shape theoretical construction; second, a group's place within the philosophical structure influences theoretical attention they are afforded. Henceforth, because older women tend to occupy a position of lower class status, especially in terms of economic status than men of all ages and younger women, they are given less theoretical attention. According to Acker (1988 cited in Arber and Ginn 1991) in all known societies the relations of distribution and production are influenced by gender and thus take on a gendered meaning. Gender relations of distribution in capitalist society are historically rooted and are transformed as the means of production change.

Similarly, age relations are linked to the capitalist mode of production and relations of distribution. "Wages" take on a specific meaning depending on age. For example, teenagers work for less money than adults, who in turn work for less money than middle-aged adults. Further, young children rely on personal relations with family figures such as parents. Many older people rely on resources distributed by the state.There is a "double standard of ageing" with age in women having particularly strong negative connotations. Older women are viewed as unworthy of respect or consideration (Arber and Ginn 1991).

Catherine Itzin sees the double standard of aging as arising from the sets of conventional expectations as to age-pertinent attitudes and roles for each sex which apply in patriarchal society. These are defined by Itzin as a male and a female 'chronology', philosophically defined and sanctioned so that the experience of prescribed roles is sanctioned by disapproval. Male chronology hinges on employment, but a woman's age 
status is defined in terms of events in the reproductive cycle (Powell, 2018).

Arguably, Arber \& Ginn (1991) claim because women's value is exercised the awareness of a loss of a youthful appearance brings philosophical devaluation; vulnerability to pressure is penetrated by cosmeticisation. Daly (cited in Arber and Ginn 1991) draws a mirror image between western cosmetic surgery and the genital mutilation carried out in some African societies: both cultured practices demonstrate the pressure on women to comply with male standards of desirability and the extent of male domination. For older black women, the ideal of 'beauty' portrayed by white male culture was doubly distant and alienating, until growing black consciousness subverted disparaging language and argued 'black is beautiful' (Powell, 2018).

Arber and Ginn (1991) claim patriarchal society exercises power through the chronologies of employment and reproduction, and through the sexualised promotion of a 'youthful' appearance in women. As a result, many older women suffer from a 'double jeopardy' thesis through age and sexual discrimination (Powell, 2018).

\section{POSTMODERN GERONTOLOGY}

In addition to these broad and macro based philosophical, there has been a vast interest in Postmodern perspectives of age and aging identity underpinned by discourses of "better lifestyles" and increased leisure opportunities for older people due to Welfareier lifestyles and increased use of biotechnologies to facilitate the longevity of human experiences (Blaikie 1999; Featherstone \& Hepworth 1993, Featherstone \&Wernick 1995 and Powell 2018). The intellectual roots of 'postmodern gerontology' derive from Jaber F. Gubrium's (1975) sociological analysis of the discovery and conceptual elaboration of Alzheimer's disease in the USA and the establishment of boundaries between 'normal' and pathological aging, old age is seen as a "mask" which conceals the essential identity of the person beneath. The view of the aging process as a mask/disguise concealing the essentially youthful self beneath is one which appears to be a popular argument (Featherstone \& Hepworth 1989, 1993). When asked at the age of 79 to describe what it felt like to be old, the author J.B. Priestley replied:
'It is as though, walking down Shaftesbury Avenue as a fairly young man, I was suddenly kidnapped, rushed into a theatre and made to don the grey hair, the wrinkles and the other attributes of age, then wheeled on stage. Behind the appearance of age I am the same person, with the same thoughts, as when I was younger' (Puner 1978: 7).

There are two underlying issues for Featherstone and Hepworth (1993) which should be understood as the basis for understanding postmodern gerontology. Firstly, the image of the mask alerts philosophical gerontologists to the possibility that a tension exists between the external appearance of the body and face and functional capacities and the internal or subjective sense of experience of personal identity which is likely to become prominent as aging traverses through the lifecourse (Powell, 2018).

Secondly, older people are usually 'fixed' to roles without resources which does not do justice to the richness of their individual experiences and multifacets of their personalities. Idealistically, Featherstone and Hepworth argue that a postmodern perspective would deconstruct such realities and age should be viewed as fluid with possibilities not constrained by medical model decline discourses (Powell, 2018).

According to Powell (2018) the direct use of new technologies to either modify the appearance or performance of ageing identity is symptomatic of postmodern times. To paraphrase Morris (1998) technologies here hold out the promise of 'utopian bodies'. Indeed, Haraway's (1991) (cited in Powell 2018) original reference to cyborgic fusion of biological and machine entities has been enthusiastically taken up by postmodern gerontology. The list of technologies available extends beyond traditional prosthesis to include virtual identities created by and reflected in the growing number of 'silver surfers' using the Internet as a free-floating form of identity management. Thus Featherstone and Wernick (1995: 3) trill that it is now possible to' Re-code the body itself 'as biomedical and information technologies make available' the capacity to alter not just the meaning, but the very material infrastructure of the body. Bodies can be re-shaped, remade, fused with machines, empowered through technological devices and extensions'.

Coupled with this, the control of the aging body had been enhanced by external constraining virtue of the 
corset, contemporary shaping has involved active working, through exercise and diet. The multiplication of magazine articles, self-help manuals, diet and exercise clubs, extending through midlife and beyond also bear witness to the popularity of attempts to work on the self in this way (Powell, 2018).

The use of diet and exercise as techniques specifically related to later adulthood, is closely related to the growth of leisure and a lifestyle approach to the creation of late life identities (Turner 1989; Powell 2018). It therefore resonates beyond the simple fuelling and repair of the bodily machine to include a continual re-creation of the self within a particular philosophical discourse. This discourse closely associates the construction of a Welfarey lifestyle with positive self-identity (Powell, 2018).

Indeed, closely related to postmodern gerontology is also a small body of knowledge pertaining to 'Foucauldian gerontology' deriving in Canadian (Katz 1996; Frank 1998) and UK (Powell 2018) academies. This Foucauldian theoretical development attempts to understand age and aging through conceptual exploration of power/knowledge and how surveillance practices, in making a controversial point here, from professionals such as 'medics' or 'workers' further marginalize, normalize and provide shape to the experiences of older people (Powell 2018).

\section{ConCLUSION}

These philosophical ideas have been at the forefront of understanding old age in US, UK and Australasian academies. Taken together, these philosophical currents have been influential in providing philosophical gerontology with a rich philosophical dimension. Such philosophicalideas have been used also to analyse pressing philosophical issues such as, elder abuse, the gendered nature of age, the politics of power relations between older people and state/society and community care. The purpose of this paper has been to amalgamate the key ideas of philosophicalphilosophies of age in order to stress the importance of philosophy to understanding age and aging (Powell, 2018).

\section{REFERENCES}

[1] Arber, S \& Ginn, J. (1991) Connecting Gender and Ageing, OUP.
[2] Arber, S. and Ginn, J. (Eds.) Connecting Gender and Ageing: a sociological approach, Milton Keynes: OUP.

[3] Baltes, P. B. (1999). The incomplete architecture of human ontogenesis. GerontologieuntGeriatrie. 32. 6: 433-448.

[4] Baltes, M. \& Carlestensen, L. (1996). The process of successful ageing. Ageing \& Society, 16, 397422.

[5] Beck, U. (1992). Risk Society: Towards a New Modernity. London: Sage.

[6] Bengtsen, V. \&Schaie, R. (1999). Handbook of Philosophical in Gerontology. New York: Springer.

[7] Biggs, S. (1993). Understanding Ageing. Milton Keynes: OUP.

[8] Biggs, S. (1996). A family concern: elder abuse in British philosophical policy. Critical Philosophical Policy. 16.2:63-88.

[9] Biggs, S. (1999). The Mature Imagination. Milton Keynes: OUP.

[10] Biggs, S and Powell, J.L. (1999). 'Surveillance and Elder Abuse: The Rationalities and Technologies of Community Care', Journal of Contemporary Welfare, 4, (1), 43-49.

[11] Blaikie, A. (1999). Ageing and Popular Culture'. Cambridge: OUP.

[12] Bowl, R. (1986). 'Philosophical work with old people' in Phillipson, C. and Walker, A. (Eds.) Ageing and Philosophical Policy. London: Gower.

[13] Bury, M. (1995). 'Ageing, Gender and Sociological Theory' in Arber, S. and Ginn, J. (Eds.) Connecting Gender and Ageing: a sociological approach, Milton Keynes: OUP.

[14] Cabinet Office. (1998).Better Government for Older People. London: H.M.S.O.

[15] Chau, W.F. (1995). 'Experts, networks and inscriptions in the fabrication of accounting images', Accounting Organisations and Society, 20, 2/3, 111-145.

[16] Chudacoff, H. (1989). How Old are You? New Jersey: Princeton. 
[17] Cohen, S. (1985).Visions of Philosophical Control. Cambridge: Polity.

[18] Cole, T., Van Tassel, D. \&Kastenbaum, R. (1992). Handbook of the Humanities and Aging. New York: Springer.

[19] Conrad, S. (1992) 'Old Age in the Modern and Postmodern Western World' in Cole, T (Ed.) Handbook of the Humanities and Ageing, New York: Springer

[20] Cousins, M. \& Hussain, A. (1984). 'Michel Foucault'. London: Macmillan.

[21] Cumming, E. and Henry, W. (1961). Growing Old: The process of disengagement. New York: Basic Books.

[22] Davidson, A. (1986). 'Archaeology, Genealogy, Ethics' in Hoy, D (Ed.). Foucault: a critical reader. Oxford: Basil Blackwell.

[23] Dittman-Kolhi. F. (1991). The construction of meaning in old age. Ageing \& Society. 10, 27994.

[24] Estes, C. (1979). The Aging Enterprise. San Francisco: Jossey Bass.

[25] Estes, C. Swan, J. and Gerard, L. (1982). 'Dominant and competing paradigms in gerontology: Towards a political economy of ageing', Ageing and Society, 12: 151-64.

[26] Featherstone, M. and Hepworth, M. (1993). 'Images in Ageing' in Bond, J. Coleman, P. and Peace, S. Ageing in Society. London: Sage

[27] Featherstone, M. \&Wernick, A. (1995). Images of Ageing. London: Routledge.

[28] Frank, A. (1998). 'Stories of illness as care of the self: a Foucauldian Dialogue', Welfare, 2, 3, 329348.

[29] Fortes, M. (1984). 'Age, Generation and Philosophical Structure' in Kertzer, D. and Keith, J. (Eds.) Age and Anthropological Theory. London: Cornell University Press

[30] Giddens, A (1993) Sociology, Cambridge: Polity Press

[31] Jones, C. (1983). State Philosophical Work and the Working Class. London: Macmillan.
[32] Jordan, B.(1996). A Theory of Poverty and Philosophical Exclusion. Cambridge: Polity.

[33] Kastenbaum, R. (1993). Encrusted elders. In Cole, T. (Ed). Voices \& Visions of Aging. New York: Springer.

[34] Katz, S. (1996). Disciplining Old Age: The Formation of Gerontological Knowledge. Charlottesville: UPV.

[35] Katz, S. (1998). 'Lifecourse, lifestyle and postmodern culture: corporate representations of later life, paper presented at Restructuring Work and the Lifecourse: An International Symposium, Institute of Human Development, University of Toronto.

[36] Laws, G. (1995). Embodiment and emplacement: identities, representation and landscape in Sun City retirement communities. International Journal of Aging \& Human Development. 40.4: 253-280.

[37] Levick, P. (1992). 'The Janus face of community care legislation: An opportunity for Radical Opportunities' in Critical Philosophical Policy, Issue 34, Summer 1992, pp.76-81.

[38] Lubove, R. (1966). 'Philosophical work and the Life of the Poor', The Nation, 23 May, pp.609-11.

[39] Moody, H. (1998). Aging, Concepts and Controversies. Thousand Oaks: Pie Forge Press.

[40] Nettleton, H., Biggs, S., Bernard, M, Knigston, P. (In press) Focus groups and older people. Qualitative Welfare Research.

[41] Neugarten, D. (Ed.). (1996). The Meanings of Age. Chicago: University of Chicago Press.

[42] Patel, N. (1990.) A Race Against Time. London: Runnymede Trust.

[43] Phillipson, C. (1982). Capitalism and the Construction of Old Age. London: Macmillan.

[44] Phillipson, C (1988). 'Challenging Dependency: Towards a new Philosophical Work with Older People' in Langan, M. and Lee, P. (Eds.) Radical Philosophical Work Today. London:Unwin Hyman.

[45] Phillipson, C. (1998). Reconstructing Old Age. London: Sage. 
[46] Phillipson, C. and Biggs, S. (1998). 'Modernity and Identity: themes and perspectives in the study of older adults, Journal of Aging and Identity, 3, 1, 11-23.

[47] Powell, J.L. and Biggs, S (2000). 'Managing Old Age: The Disciplinary Web of Power, Surveillance and Normalisation', Journal of Aging and Identity, 5, 1, 3-13.

[48] Powell, J.L and Cook, I (2000) 'A Tiger Behind and Coming Up Fast: Governmentality and the Politics of Populational Control', Journal of Aging and Identity, 5,2, 79-91.

[49] Powell, J. (1999), 'The Importance of a 'Critical' Sociology of Old Age', Philosophical Science Paper Publisher, 3, 1.

[50] Powell, J. (2018), Lifecourse and Society. New York: Nova Science

[51] Rabinow, P. (Ed.). (1984). The Foucault Reader. Paris: Peregrine.

[52] Satyamurti, C. (1974). 'Women's Occupation and Philosophical Change: the Case of Philosophical Work, paper presented to 1974 British Sociological Association's Annual Conference.

[53] Shilling, C. (1993). The Body and Identity. London: Routledge.

[54] Shumway, D. (1989). Michel Foucault, Charlottesville: University Press of Virginia.
[55] Smart, B. (1985). Michel Foucault. London: Routledge.

[56] Townsend,P. (1981). The Structured Dependency of the Elderly: A Creation of Philosophical Policy in the Twentieth Century' in Ageing and Society, Vol.1, No.1, pp.5-28.

[57] Turner, B. (1989). 'Ageing, Status Politics and Sociological Theory' in British Journal of Sociology, 40: 588-606.

[58] Turner, B. (1995). Ageing and identity. In Featherstone, M. \&Wernick, A. Images of Ageing. London: Routledge.

[59] Veyne, P. (1980). Foucault revolutionnel'histoire. Paris.

[60] Wahidin, A and Powell, J (2001) 'The Loss of Aging Identity: Philosophical Theory, Old Age and the Power of Special Hospitals', Journal of Aging \& Identity, 6, 1, 31-49.

[61] Walker, A 'Towards a Political Economy of Ageing', Ageing \& Society, 1, 2, 23-44.

[62] Wilson, G. (1991). 'Models of ageing and their relation to policy formulation', Policy \& Politics, 19, 1, 37-47.

[63] Woolfe, R. and Biggs, S. (1997). Counselling older adults. Counselling Psychology Quarterly. 10.2: 189-94.

Citation: Jason L. Powell. Philosophy, Welfare and Aging. Open Journal of Geriatrics. 2018; 1(2): 7-14. Copyright: (C) 2018 Jason L. Powell. This is an open access article distributed under the Creative Commons Attribution License, which permits unrestricted use, distribution, and reproduction in any medium, provided the original work is properly cited. 